\title{
A Study on the Path of Ideological and Political Education in Professional under the Background of Internet — Taking the Applied Economics and Management Specialty Curriculum as an Example
}

\author{
Shuchen Yang ${ }^{1}$ Xiaoyun Duan ${ }^{2}$ Xiang Gao ${ }^{3 *}$ \\ Jiangxi Tourism\&Commerce Vocational College, Nanchang,Jiangxi,330000,China
}

\begin{abstract}
The development of Internet and information technology brings reform direction to the teaching of applied colleges and universities, and it is also a more severe challenge for students' ideological and political education. The open communication mode under the background of the Internet makes the information received by students in their daily life more and more diversified, among which contradictory and low quality information makes students at a loss. As the main learning content of cultivating and guiding students, professional courses should make full use of the technical advantages of the Internet and strengthen the ideological and political education and guidance to students. Based on the analysis of the necessity of ideological and political education, this paper puts forward the feasible path of ideological and political education to realize the high quality development of college students.
\end{abstract}

\section{INTRODUCTION}

During the Internet era, students can obtain diversified information through online channels such as network links, dating platforms, games APP、shopping platforms, online learning platforms, and so on. However, due to the influence of platform virtualization, network management and various ideological conflicts, the information obtained by students has serious problems in the aspects of authenticity and value guidance, and some will even mislead students' understanding of the outside world. Therefore, it is necessary for colleges and universities to guide students to form a correct understanding of external information through ideological and political education in the curriculum, and to constantly cultivate college students to establish a correct outlook on life, study and material. As the main learning course of applied college students, professional courses play an important role in the education and enlightenment of college students. Therefore, colleges and universities should give full play to the role of ideological and political education in professional courses so that students can form correct moral norms, ideological understanding and political ideas. This paper takes the applied economics and management courses as an example, and will focus on the ideological and political education path of the professional courses.

\section{THE CONNOTATION OF IDEOLOGICAL AND POLITICAL EDUCATION IN THE COURSE OF MANAGEMENT SPECIALTY IN APPLIED COLLEGES AND UNIVERSITIES}

\section{A. The Necessity of Ideological and Political Education in Management Courses}

General Secretary Xi's speech at the 2016 ideological and political conference in colleges and universities pointed out the direction for colleges and universities to carry out ideological and political education for college students. Colleges and universities should adhere to the fundamental purpose of building people and effectively integrate socialist core values into daily teaching and students' ideological education. The academic culture and curriculum resources in colleges and universities can be used as the resources of ideological and political education, and finally promote the high unity of "curriculum ideological and political" and "ideological and political curriculum "[1].

The major of management in applied colleges and universities is mainly to train professionals in the field of finance and management, which is related to the economic development of the country and the property safety of the people. Assuming that the cultivation of

\footnotetext{
*Corresponding author's e-mail: 739960103@qq.com
} 
students majoring in economics and management is separated from the work of ideological and political education, although students have solid professional knowledge and excellent professional skills, they seriously lack ideological and moral understanding and standards of conduct. Once these students go to society, there is a great threat to social economy, enterprise development and individual growth of students.

Almost $2 / 3$ of the students majoring in economics and management spend their time on the study of professional courses. Because the study of major is related to the development of students after graduation, teachers and students attach great importance to it. Therefore, the professional courses of economic management should give full play to the function of ideological and political education, combine ideological and political elements with professional knowledge, not only teach students knowledge and skills, but also teach students the basic principles of being a man and doing things. Truly realize the all-round cultivation of talents.

\section{B. Objective of Ideological and Political Education in Management Courses}

According to the talent training goal of the economics and management specialty in the applied colleges and universities, it can be found that the overall goal of the teaching of the economics and management course should be to realize the students' macroeconomic judgment and analysis ability, the comprehensive management ability, the learning and application ability of the professional knowledge and the sound personality. It can be seen that in the process of construction, the management course should not only realize the cultivation of students' professional knowledge and ability, but also lead the students' moral consciousness and behavior standard. In addition, ideological and political education in economic management

courses should also pay attention to the cultivation of students' innovative consciousness and ability[2]. Teachers should pass on value experience and behavior norms to students in the form of evidence through real situations. In order to test students' learning results and ideological improvement, teachers should evaluate students' comprehensive performance. In the process of teacher evaluation, students should communicate one to one, and find out the problems of cognition, values and moral concepts in the process of communication and correct them in time.

\section{CURRENT SITUATION OF IDEOLOGICAL AND POLITICAL EDUCATION IN MAJOR COURSES OF MANAGEMENT}

Like the ideological and political education of other specialties, the ideological and political teaching department, the league committee and the counselors are also the main manifestations of the ideological and political theory. However, at present, the ideological and political education of professional courses only stays at the edge position, and the major colleges and universities only put forward the requirements of ideological and political education for professional teaching, but there is no feasible implementation plan and quantitative assessment standard. Many professional teachers carry out ideological and political education through open courses or pilot courses, while other professional courses rarely involve ideological and political work. Therefore, the course of ideological and political education is not mature, the specific performance is as follows:

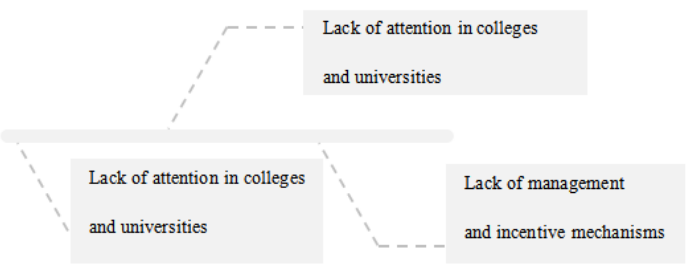

Figure 1.Current Situation of Ideological and Political Education in Major Courses of Management

\section{A. Lack of attention in colleges and universities}

From the point of view of running a school, college managers usually pay more attention to the passing rate of grade examination, the achievement of students' competition, the number of scientific research, the rate of promotion and the employment rate, but pay little attention to the psychological growth and moral development of students. In addition, because ideological and political education belongs to the category of ideology, it is difficult for teachers to accurately observe and find out the potential ideological or moral problems of students, so it is difficult for teachers to carry out teaching guidance and evaluation work.

\section{B. Lack of harmonized management and incentive mechanisms}

If colleges and universities want to realize the transformation from "ideological and political curriculum" to "curriculum ideological and political ", they must ensure that every teacher and university worker are involved in the ideological and political education of students. However, different teachers and managers come from different colleges and departments, and it is difficult to manage them uniformly because of the different affiliations and educational responsibilities. In addition, the curriculum evaluation system of management major rarely involves the content of ideological and political assessment, but also lacks the consideration of ideological and political elements in teachers' teaching display, achievement evaluation and competition award. For example, the professional title evaluation of college teachers is still from the teaching construction workload[3], teaching assessment, scientific research completion, competition awards and other aspects of the establishment of assessment indicators, but teachers' ideological and political level and ideological and 
political education for students are not required.

\section{Teaching design is not scientific and comprehensive}

Ideological and political education in professional courses is mainly carried out in classroom teaching, including theoretical courses, experimental training courses and practical courses. Although some teachers have carried out relevant ideological and political education in the classroom, the way of education is stiff and the content is not rich enough to arouse the students' enthusiasm for learning. Because the degree of closeness between teaching content and ideological and political elements is not enough, the content of classroom teaching presents the characteristics of fragmentation, which can not only guide students' values, but also hinder students' understanding and digestion of learning content.

\section{INFLUENCING FACTORS OF IDEOLOGICAL AND POLITICAL EDUCATION IN MAJOR COURSES OF MANAGEMENT}

\section{A. Ideological and Political Education}

In order to realize the reform of ideological and political education, colleges and universities must first change the concept of educating people. For a long time, the main reason for the ideological and political education in colleges and universities is that educators fail to establish the educational concept of ideological and political education. Most teachers tend to the former in the teaching of knowledge and the choice of students' values, because the teaching of knowledge is explicit and easy to assess, and the values are implicit and difficult to assess. At the same time, most teachers think that ideological and political education should be the responsibility of ideological and political theory teaching department or professional ideological and political teachers, which has nothing to do with themselves, so they fail to actively help students cultivate their values in the teaching process. Under the influence of solidified thinking, the teaching of management courses is very difficult in the process of transforming academic resources and subject resources into ideological and political education. However, according to the goal of talent training and the fundamental requirements of teaching and educating people, college teachers must realize the organic integration between knowledge transfer and value guidance. Teachers who cooperate with the ideological and political theory teaching department to carry out ideological and political education should also actively and actively realize the education of students' ideological understanding and political level in their own curriculum construction and teaching process[4].

\section{B. Teachers' strength}

On the one hand, teachers' individual moral understanding and comprehensive accomplishment will affect the effect of curriculum ideological and political implementation, on the other hand, once the teachers of various colleges and majors in colleges and universities form educational forces, they can promote the ideological and political work of students to move forward in a unified direction. To the individual teacher, the teacher of management specialty should be the teacher with ideal, sentiment, knowledge and love. Because the teacher's ideal, sentiment and morality will influence the students imperceptibly in the daily teaching, so as to further improve the students' moral level. Due to the integration of many western ideas and development techniques, the courses of management major have obvious openness. Teachers play an important role in guiding students how to treat the essence of capitalist economy by objectively imparting western management theory and economic knowledge. If teachers themselves can not correctly analyze the essence of capitalist economy, it is difficult for students to realize its backwardness and the essence of profit-seeking.

\section{The power of faculties}

Ideological and political education is a systematic project, we must form the "three full education" reform concept. All responsible departments and colleges should closely unite and cooperate with each other to form a joint force in ideological and political education. As the first responsible department of teaching, the college should give full play to the main role of running a school and actively assist all departments and teachers to integrate ideological and political education into teaching plans and personnel training[5]. The college should fully excavate the elements of ideological and political education from the perspective of talent training program, syllabus, curriculum standard, teaching plan, class time arrangement and so on, and carry out the ideological and political work. In addition, the college should give full play to the role of the director of the teaching and research office and the director of the teaching and research office, divide the ideological and political work into pieces, and realize the transformation of the ideological and political work from recessive education to explicit education. For example, for accounting, logistics, finance and other related majors, the teaching and research office should clearly integrate the ideological and political teaching requirements into the teaching and design of the course, so as to ensure that the teaching objectives and teaching links of each chapter can reflect the function of educating people.

\section{THE PATH ANALYSIS OF IDEOLOGICAL AND POLITICAL EDUCATION IN THE COURSE OF MANAGEMENT SPECIALTY}




\section{A. Strengthen the consciousness of educating people and improve the ideological and political literacy of the curriculum}

Colleges and universities should fully realize the important role of teachers, educators and managers in ideological and political education. As a professional place to train talents to meet the needs of society and national development, colleges and universities should create a good campus environment and curriculum environment for the development of students' physical and mental health. As the main person in charge of the major of economic management, the dean of the college and the school leader should consciously establish the consciousness of ideological and political education, and carry out the moral cultivation of the students into the concrete professional construction and management system. Each college should actively establish the educational goal of theoretical curriculum and practical training course, encourage teachers to actively explore the ideological and political education of professional curriculum, and further strengthen the endogenous motive force of curriculum ideological and political education.

\section{B. Improve the curriculum construction and management mechanism to ensure the implementation of ideological and political education}

Ideological and political education only depends on the enthusiasm of teachers and the participation of various departments is far from enough. Because of the systematization and comprehensiveness of ideological and political work, the ideological and political work in colleges and universities must have a perfect system to ensure the coordination and cooperation between various departments. Colleges and universities should establish perfect training mechanism of ideological and political team and supervision[6], examination and reward mechanism of ideological and political work. Only by carrying out the concept of education in every teaching activity can colleges and universities realize the effect of curriculum education as a whole. Because the ideological and political elements of the course of economics specialty have extensive and profound characteristics, each college should closely focus on the goal of educating people, urge each teaching and research department to establish a clear ideological and political teaching goal, teaching plan, evaluation mechanism and so on. Each teaching and research department should also play the responsibility of unified management and encourage the teachers of this teaching and research department to carry out the idea, content and way of ideological and political education consciously.

\section{Implement the main position of students and innovate the teaching methods of professional courses}

The ultimate goal of curriculum ideological and political education is to realize the high quality and sustainable development of talents. In this process, colleges and teachers should recognize the main position of students in ideological understanding and moral development. Teachers should guide college students to correctly understand the responsibility and mission entrusted by the times, and consciously set up lofty ideals and correct outlook on life and values. Because the specialty of management is closely related to the economic development of the country, the talents of this specialty will go to all enterprises and economic posts in the economic market, so it has an important influence on improving the competitiveness of enterprises and standardizing the market environment. In view of this, teachers should actively innovate the teaching methods of professional courses, enrich the interest of the classroom, improve the inspiration of teaching, and give full play to the educational function of professional courses.

\section{CONCLUSION}

In the new period, the ideological and political education work of colleges and universities should recognize the current situation and fully mobilize all parties in colleges and universities to participate actively. Teachers of all disciplines should consciously strengthen the sense of urgency and responsibility of ideological and political work in their daily teaching, start from their own, and implement the concept of ideological and political education into the classroom activities of each teaching design. At the same time, each college should actively promote the transformation of "ideological and political curriculum" to "curriculum ideological and political transformation ", strive to excavate the educational elements of each professional curriculum, and establish a standardized curriculum management mechanism. The ideological and political work in colleges and universities is only carried out, not completed. Both leaders, workers and front-line teachers in colleges and universities should actively realize the combination of professional knowledge and value rationality, and train more and more comprehensive professionals for the development of the nation and the economic take-off.

\section{REFERENCES}

1. Xiao,P.Su,J.He,X.(2020)Discussion on the Reform of Education and Teaching of Economic Major in the Perspective of Ideological and Political Curriculum[J].Modernization of education.

2. Zhao,L.J.Wang,J.H.(2020)A Research Report on the Construction of "Curriculum Thought and Politics" for Economic Management Specialty in Higher Vocational Colleges — - Taking the "Double High" Construction of Higher Vocational Colleges in Shaanxi Province as the research object[J].Journal of Jiamusi Vocational College.

3. Zhao,L.J.Tian,J.P.(2020)Analysis on the Realization Path of "Ideological and Political Course" for Economic Management Specialty in Higher 
Vocational Colleges[J].Classic.

4. Chen,X.L.Zhang,X.Y.(2019)Study on the Realization Path of "Ideological and Political Course" Construction in Economics Specialty: Taking Economic History as an Example[J].Study on Ideological and Political Studies.

5. Lu,Y.X.Gao,P.(2019)Considerations on Ideological and Political Education in Professional Curriculum Based on the Concept of "Three Full - -
Education "- - Taking Agricultural Economic Management Specialty as an Example[J].Journal of Heilongjiang Ecological Engineering Vocational College.

6. Liu,Y.X.(2019)Analysis on the Reform of Ideological and Political Teaching in the Course of Tourism Management in Independent College under the Background of Economic Globalization[J].Marketing. 